2016

\title{
Investment Treaties and the Internal Vetting of Regulatory Proposals: A Case Study from Canada
}

Gus Van Harten

Osgoode Hall Law School of York University, gvanharten@osgoode.yorku.ca

Dayna Nadine Scott

dscott@osgoode.yorku.ca

Follow this and additional works at: https://digitalcommons.osgoode.yorku.ca/olsrps

Part of the Law Commons

\section{Recommended Citation}

Van Harten, Gus and Scott, Dayna Nadine, "Investment Treaties and the Internal Vetting of Regulatory Proposals: A Case Study from Canada" (2016). Osgoode Legal Studies Research Paper Series. 151.

https://digitalcommons.osgoode.yorku.ca/olsrps/151 


\title{
OSGOODE HALL LAW SCHOOL \\ LEGAL STUDIES RESEARCH PAPER SERIES
}

Research Paper No. 26

Volume 12, Issue 6, 2016

\section{Investment Treaties and the Internal Vetting of Regulatory Proposals: A Case Study from Canada}

\author{
Gus Van Harten \\ Dayna Nadine Scott
}

This paper can be downloaded free of charge from:

http://ssrn.com/abstract=2700238

\begin{abstract}
Further information and a collection of publications from the Osgoode Hall Law School Legal Studies Research Paper Series can be found at:

http://www.ssrn.com/link/Osgoode-Hall-LEG.html
\end{abstract}

\section{Editors:}

Editor-in-Chief: Carys J. Craig (Associate Dean of Research \& Institutional Relations and Associate Professor, Osgoode Hall Law School, York University, Toronto)

Production Editor: Kiana Blake (Osgoode Hall Law School, York University, Toronto)
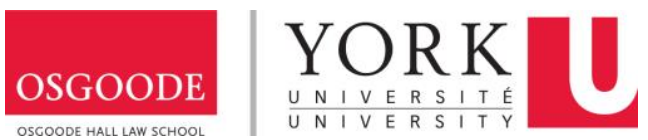
Osgoode Legal Studies Research Paper No. 26

Vol. 12/ Issue. 6/ (2016)

\title{
Investment Treaties and the Internal Vetting of Regulatory Proposals: A Case Study from Canada
}

\author{
Gus Van Harten \\ Dayna Nadine Scott
}

\begin{abstract}
:
In this paper, we report findings on whether trade and investment agreements that allow for investor-state dispute settlement (ISDS) contribute to regulatory chill. The study focused on whether ISDS contributed to changes in internal vetting of government decisions related to environmental protection in the province of Ontario, Canada. Our main source of information was confidential interviews with insiders, mostly current or former officials in ministries with an environmental or trade mandate. We aimed to advance understanding of litigation risk and government decision-making with a focus on ISDS.
\end{abstract}

\section{Keywords:}

ISDS, arbitration, regulation, regulatory chill, litigation risk, environmental protection

\section{Author(s):}

Gus Van Harten

Osgoode Hall Law School

E: gvanharten@osgoode.yorku.ca
Dayna Nadine Scott

Osgoode Hall Law School

E: dscott@osgoode.yorku.ca 
Investment Treaties and the Internal Vetting of Regulatory Proposals: A Case Study from Canada

Gus Van Harten and Dayna Nadine Scott

Introduction

Do trade agreements and investment treaties that allow for investor-state dispute settlement (ISDS) lead to regulatory chill? Some researchers express the concern that ISDS creates incentives for states to avoid or modify their regulatory decisions because of a risk of foreign investor claims and monetary awards. ${ }^{1}$ The fear is usually linked to the exclusive access of foreign investors to ISDS, the inability of states to bring claims against foreign investors, the breadth of foreign investor protections in ISDS, the weaknesses of exceptions to protect the right to regulate, the ability of foreign investors to receive uncapped amounts of compensation from the state, the international enforceability of ISDS awards, or the absence of conventional judicial safeguards in ISDS. ${ }^{2}$ The fear is also raised often in the context of health and environmental decisionmaking. 3 Concerns about regulatory chill point to the broader issue of how legal constraints and litigation risk affect the state's regulatory enterprise by restricting policy space and raising public costs of state activities. 4

In this paper, we report empirical findings on ISDS and regulatory chill. Our study focused on whether ISDS contributed to changes in internal vetting of government decisions related to environmental protection in the province of Ontario, Canada. Our main source of information was 51 interviews, conducted on a confidential basis with insiders, mostly current or former officials in ministries with an environmental or trade mandate. We aimed to advance understanding of litigation risk and government decision-making in general with a particular focus on ISDS. 5 Our first set of findings are as follows: ${ }^{6}$

\footnotetext{
${ }^{1}$ J. Clapp, "Global Environmental Governance for Corporate Responsibility and Accountability" (2005) 5:3 Global Environmental Politics 23; C. Tollefson and W.A.W. Neilsen, "Investor Rights and Sustainable Development" in K. Gallagher, ed., Handbook on Trade and the Environment (Cheltenham, Edward Elgar: 2008); S. Clarkson and S. Wood, A Perilous Imbalance: The Globalization of Canadian Law and Governance (Vancouver: UBC Press, 2010).

${ }^{2}$ G. Van Harten, Investment Treaty Arbitration and Public Law (Oxford: OUP, 2007), ch 5 and 7.

3 K. Tienhaara, The Expropriation of Environmental Governance (Cambridge: CUP, 2009), ch 8; K. Cooper et al, "Seeking a regulatory chill in Canada: The Dow AgroSciences NAFTA Chapter 11 Challenge to the Québec Pesticides Management Code" (2014) 7(1) Golden Gate University Environmental Law Journal 5 .

4 T. Prosser, The Regulatory Enterprise (Oxford: OUP, 2003); J. Braithwaite and P. Drahos, Global Business Regulation (Cambridge: CUP, 2000).

5 D. Schneiderman, Constitutionalizing Economic Globalization: Investment Rules and Democracy's Promise (New York: CUP, 2008).

${ }^{6}$ We plan to report additional findings in further publications.
} 
1. Government ministries have changed their decision-making to account for trade concerns including ISDS.

2. Government lawyers play a key role in assessing trade and ISDS risks.

3. The Ontario trade ministry has pushed to expand a centralized regulatory assessment process for evaluating proposed government decisions for trade and ISDS risks.

4. Some insiders saw the trade ministry and the regulatory assessment process as creating undesirable obstacles for environmental decision-making.

5. A ministry's concern for trade and ISDS was more acute after the ministry was drawn into a NAFTA case although institutional learning about ISDS appeared to be variable and intermittent.

6. Officials typically declined to discuss specific cases or decisions.

7. Officials referred occasionally to specific situations where trade or ISDS concerns were considered and, in some cases, where they led to changes to a proposal.

These findings are not exhaustive and will be supplemented by more detailed findings that are flagged in the conclusion to this article. We stress also that the context of Ontario, Canada, may differ significantly from other jurisdictions. Even for Ontario, the findings are not comprehensive; we think they are best viewed as investigative revelations emerging from somewhat scattered insider perspectives. The perspectives were somewhat scattered because some officials contacted for an interview did not accede and those who did accede worked in different contexts of government. We have exercised caution in presenting the findings by emphasizing observations that were supported by multiple interviewees and by prioritizing the direct reporting of interviewee statements in order to allow the reader to evaluate support for each finding.

\section{Background}

\section{A. The context of Ontario, Canada}

Ontario is the largest province in Canada. It has significant foreign ownership of its economy, which mixes manufacturing, services, resources, and agriculture. As part of Canada's federalist system, Ontario has its own legislature and government.7 Various ministries have a role in environment-related decision-making, including the ministries

7 To preserve the confidentiality of interviewees, the environmental commissioner's office is called a ministry here although it is in fact a government agency. 
of agriculture, environment, energy, natural resources, northern development and mines, and the environmental commissioner's office. We interviewed officials in four of these ministries and at the provincial trade ministry, then called the Ministry of Economic Development and Trade.

Canada has had relatively high exposure to ISDS claims. It is the only Western country to have accepted ISDS comprehensively with the U.S. and thus to have subjected a very large part of its foreign-owned economy to ISDS. Canada has been in this position for two decades under the North American Free Trade Agreement. ${ }^{8}$ NAFTA entered into force in 1994, a few years before the explosion of ISDS claims by foreign investors in the late 1990 s began.

Since 1997, Canada has been sued 36 times in ISDS under NAFTA, in all but one insignificant case by U.S. investors. 9 Of the 36 cases, the federal trade department reports that 16 were withdrawn or abandoned, although some of these cases appear to have led to a confidential settlement with the foreign investor. Another 13 of the 36 cases were resolved in an ISDS adjudicative process with a mixed record for Canada of six wins and seven losses (based simply on whether or not compensation was paid or ordered for the foreign investor). ${ }^{10}$ The other 6 of the 36 ISDS cases are ongoing. ${ }^{11}$ Of the 36 cases not withdrawn or inactive, 4 cases involved challenges to Ontario decisions. Of those, one was won by Canada and one was lost - based on an apparent monetary settlement paid by Ontario - and two are ongoing. ${ }^{12}$

Some aspects of this context appear to raise the likelihood of regulatory chill linked to ISDS. Canada has been exposed to ISDS with the U.S. for about 20 years and Ontario has made decisions aimed at environmental protection that have led to ISDS claims against Canada. ${ }^{13}$ From 2003 to 2008, in the Ontario Liberal government's first five years in office, Ontario pursued an ambitious environmental protection agenda. ${ }^{14}$ Further, the Ontario government is large and well-funded and therefore presumably well-informed about ISDS. Yet other aspects appear to reduce the likelihood of

\footnotetext{
${ }^{8}$ North American Free Trade Agreement (NAFTA).

9 For a list of NAFTA Chapter 11 cases against Canada, see http://www.international.gc.ca/tradeagreements-accords-commerciaux/topics-domaines/disp-diff/gov.aspx?lang=eng (Foreign Affairs, Trade, and Development Canada) (last accessed 4 November 2015).

${ }^{10}$ Ibid. Cases subject to a formal process in which Canada did not pay compensation: Centurion; Chemtura; Dow AgroSciences; Gallo; Merrill \& Ring; UPS. Cases in which Canada did pay compensation: AbitibiBowater; Bilcon; Ethyl; Murphy/ Mobil Oil; Pope \& Talbot; SD Myers; St Marys.

${ }^{11}$ Ibid. e.g. Eli Lilly; Lone Pines. The 6 ongoing cases mentioned here do not include 2 new claims by Murphy/ Mobil Oil that are also ongoing but connected to the claimants' win in an earlier case.

${ }_{12}$ Ibid. The cases involving Ontario are Gallo; Mesa Power; St Marys; Windstream.

13 The cases involved a proposed landfill (Gallo), a proposed quarry (St Marys), and the implementation of the Green Energy Act (Mesa Power and Windstream Energy).

14 M. Winfield, Blue-Green Province: The Environment and the Political Economy of Ontario (UBC Press, 2012). Several interviewees pointed to examples of regulatory efforts during this period, such as the government's decisions to phase out coal power, enact a greenbelt conservation plan, raise drinking water standards, enact green energy legislation, and restrict cosmetic use of pesticides.
} 
regulatory chill. Ontario's decisions have not led to a large number of ISDS cases or to a loss in an actual award. Ontario's decisions have not led to cases as that are as high profile as in other Canadian jurisdictions. ${ }^{15}$ Canada has a well-established court and tribunal system that allows for independent dispute resolution between businesses and government. According to various interviewees, provincial officials tend to assume that trade and ISDS concerns are a federal not a provincial responsibility. Finally, according to a few interviewees from outside Ontario, Ontario's size may make it less sensitive than other provinces to pressures linked to trade and ISDS.

\section{B. Method}

We did 52 interviews with persons inside and outside government, focusing on current or former government officials. ${ }^{16}$ Interviewees were contacted through past contacts and snowballing, cold-call invitations in relevant ministries, and a few interviews responding to access-to-information requests in two provinces other than Ontario. ${ }^{17}$ Our cold-call invitations were sent systematically to officials in mid-level management positions and were designed to counteract possible selection bias in snowballed interviews. They made up about one third of total interviews.

The interviews were semi-structured and open-ended. We tried to engage interviewees in conversation. Typically we began with general questions about litigation risk in government and then proceeded to more specific questions about ISDS or ISDS-related situations. We did not press for details about specific situations and conveyed that our priority was to make general findings, not to question individuals' or organizations' choices in specific cases. Our general rubric of questions was as follows. What is your professional background? What is your role in government decision-making? Are you familiar with issues of litigation risk (possible prompt: judicial review, constitutional challenges, trade challenges)? Alternatively: do you deal with lawyers inside government? How does government account for litigation risk? Does your work involve any trade or investment agreements (possible prompt: NAFTA or the World Trade Organization (WTO))? Does your work involve investor-state dispute settlement (ISDS), also known as investment arbitration or NAFTA Chapter 11 arbitration? Have you heard of any ISDS or NAFTA cases (possible prompt: mention specific cases that appear relevant). After explaining in more detail how ISDS works, for those not familiar with it, and how its monetary remedy differs from judicial review or the WTO: do you think

\footnotetext{
${ }_{15}$ Higher profile cases have involved the federal government (Eli Lilly; Ethyl; SD Myers); Newfoundland and Labrador (AbitibiBowater); Nova Scotia (Bilcon); and Quebec (Lone Pines).

${ }^{16}$ Ten interviews involved foreign jurisdictions and were treated as peripherally relevant. They were reviewed to ensure no direct contradictions with the findings reported here. However, no corroborating statements were added from these interviews because there was not as in-depth a background review of each jurisdiction.

${ }_{17}$ Braithwaite and Drahos, above n 4, 12.
} 
risks of ISDS affect government decision-making? Questioning could vary, especially if it was evident that the interviewee had good knowledge of ISDS. 18

Between them, the researchers have expertise in trade law, ISDS, and health and environmental regulation. Both researchers were present in the interviews except where scheduling made this unfeasible. Both researchers reviewed all interview transcripts and discussed their observations. Transcripts were also reviewed systematically by a research assistant to identify themes and findings. ${ }^{19}$ When weighing information, several issues were considered; most importantly, more weight was put on unprompted statements that appeared to be unconnected to prior judgments on trade or ISDS and more weight was put on statements by persons who had direct government experience.

Interviews were premised on broad confidentiality assurances in order to encourage participation and candid discussion. As a result, all findings are reported on an anonymous basis. We have avoided identifying any specific ministry, position, or role of an official to prevent other insiders from identifying interviewees. Footnotes are used to identify statements originating from the same interviewee.

Our most reliable findings, though tentative, are for Ontario government decisionmaking on environmental issues. In total, 20 interviewees had insider experience in four relevant ministries and another 11, including 6 from health or environmental organizations and 5 who were trade lawyers or business representatives, had relevant outsider experience in Ontario or federally. We also interviewed 11 officials in the federal government or another provincial government and 10 from other countries. These interviews were used to provide context for Ontario and for the limited purpose of checking for contradictory evidence. To the extent that our findings relate to other jurisdictions, they emerged from a smaller number of interviews and a less systematic approach to interview requests. Even for Ontario, the findings should be approached with caution; they emerge from an apparently small but significant number of semirandom pieces collected from a large, multi-layered puzzle of government decisionmaking.

II. Findings

A. ISDS and government decision-making

Finding \# 1: Government ministries have changed their decision-making to account for trade concerns including ISDS.

\footnotetext{
${ }^{18}$ Detailed knowledge of ISDS was assumed for five interviewees from a trade ministry in Ontario or another province, one from an environment-related Ontario ministry, one from the federal government, two who were Ontario trade lawyers, and five from other countries.

19 F. Bechhofer, B. Elliot, and D. McCrone, "Safety in Numbers: On the Use of Multiple Interviewers" (1984) 18 Sociology 97.
} 
It was clear that various ministries considered in their internal processes the risk of ISDS claims under NAFTA and, more broadly, compliance with trade agreements. To illustrate, a government lawyer in an environment-related ministry reported that trade issues began to cross the lawyer's desk after the early 2000s. Asked what trade issues tended to come up, the lawyer pointed to the WTO and the ISDS provisions in NAFTA Chapter 11, remarking that "Chapter 11 is the one that really bites". The lawyer reported reviewing one or two, sometimes three or four, proposals for legislation, a regulation, or a policy each year for trade compliance. The lawyer said that this area of review occupied a significant proportion of the lawyer's time. ${ }^{20}$

A former official in the same environment-related ministry, who worked in a high-level advisory role, was also aware of the risk of NAFTA ISDS claims. In response to a general question about litigation risk in government, the former official said that NAFTA Chapter 11 was an important consideration: ${ }^{21}$

Q How does what we're referring to as litigation risk to government or state liability - how if at all does that factor into [internal decision-making] alongside other factors? And what degree of weight would be placed on it and what types of litigation risk would we be talking about?

A: I would say that, first of all, there's definitely an issue of litigation risk affecting decision making and I'll talk more about the types. The ones that come to mind more readily for me are allegations around Chapter 11 claims under NAFTA as opposed to the reality of whether those would be born out.

Later in the interview, the former official stated that NAFTA Chapter 11:22

was often raised as, you know, 'we're hearing from stakeholders about this, we don't know if we can do it, we're worried, we might have to get an opinion....' I shouldn't say quite often but sometimes policy measures were actually held up while they got opinions about NAFTA or Chapter 11 risk.

The former official explained that the NAFTA concerns were raised by civil servants or lawyers in the environment-related ministry and that the cited "stakeholders" could have been colleagues in the provincial trade ministry or in industry. The former official suspected the former. ${ }^{23}$

An official in the same ministry who worked on project approvals was asked if trade implications under NAFTA or the WTO could be raised by a proponent when pressing

\footnotetext{
${ }^{20}$ Interview with AH (25 March 2013).

${ }^{21}$ Interview with AE (15 April 2011).

22 Ibid.

23 Ibid.
} 
for the approval of a project. The official said: "Yes I think it could. I absolutely think it could." 24

An official in another environment-related ministry was asked specifically about ISDS and regulatory change and whether government decision-makers are "really aware of these mechanisms at all" and whether it is "realistic to think governments are actually going to change their decisions". The official replied: "I would say that yes, I think there's an awareness. I think there's a desire to avoid those kinds of situations." 25

An official in another environment-related ministry who develops policy proposals was asked generally about how proposals are vetted for legal risks. The official said: 26

As a little policy shop, working with our colleagues in other ministries, we'll sort of float a particular proposal and then we'll have our lawyers take a look at it and they'll sort of talk to their colleagues in the other ministries and just see like, okay so is this something that's feasible, does this get us into any trouble, is this in keeping with the legislation on the books right now, is this in keeping with current regulation, are we looking at any potential changes?

So you're constantly working on narrowing down your set of options and every option, I mean especially as we start getting down to our last few, they have to be vetted by our legal folks.

A lawyer in the same ministry reported that the ministry had a small number of lawyers who were trade law experts and that the ministry had been involved in NAFTA-related situations. ${ }^{27}$

A well-placed source in the Ontario trade ministry said that other ministries would sometimes contact the trade ministry for advice on how to design proposals in light of trade issues. According to the source, the environment ministry was "one of our better ministries in terms of the ones that refer things to us and they've been very loyal followers of [the trade ministry's] trade policy seminars". The source added: 28

So they are I think more aware of it than some others.... There are some ministries that seem to have internalized their messages a little bit and can actually act as a preliminary filter on their own. MOE [ministry of the environment] is one of them.

\footnotetext{
24 Interview with AK (3 October 2013).

25 Interview with BP (14 July 2014).

${ }^{26}$ Interview with BJ (28 March 2014).

27 Interview with BG (27 February 2014).

${ }^{28}$ Interview with AF (15 April 2011).
} 
From a higher-level perspective, a former political advisor who had extensive access to Ontario Cabinet decision-making stated:29

there's always a legal analysis to anything... that goes up [to Cabinet] period, for any kind of decision. So if there's legal risk, you're going to know about it. And if it's unknown, then they're going to tell you about it. And a lot of trade law is done that way.

The role of trade issues in internal decision-making was also flagged by officials in other jurisdictions in Canada. A former federal Cabinet minister stated that, before a proposed decision reached the stage of a minister bringing it to Cabinet or another ministry, there was consideration of trade agreements and the risk of trade challenges. When asked about the impact of threatened ISDS claims, the former minister clarified: "You don't have to be even threatened before it is a factor in your decision making process." 30

In another large Canadian province, a trade ministry official, who was interviewed with two junior colleagues, said that proposed measures in that province were reviewed for trade compliance on hundreds of occasions each year and that the trade ministry had a team of a dozen people. The measures reviewed could include legislative, regulatory, or policy changes or existing policies. According to the official: "Basically a trade lens is applied through the Cabinet process" including for internal trade issues, WTO, and NAFTA. When asked about NAFTA Chapter 11, the official said, "Absolutely it's on the radar". ${ }^{31}$

This official also said that other ministries could review trade concerns without involving the provincial trade ministry. The latter ministry would "only see issues when investment experts in [another] ministry suggest it's a good idea" and that "many times we won't see an investment proposal because it's screened out by a ministry's own folks". The official explained that there are informal and formal means to review trade concerns and that, in most cases, the review takes the form of "an informal heads up on thoughts and proposals" meaning that things can "get scuttled and shelved at an early stage". Formal reviews of proposals might be requested by a director, executive director, or assistant deputy minister from another ministry. ${ }^{2}$

Another trade specialist in a ministry in a smaller province said that trade issues were reviewed in the ministry's advice to Cabinet. The exchange was as follows:33

A We'd look at the relevant trade agreement and what implications they have.

\footnotetext{
29 Interview with AX (22 November 2013).

$3^{\circ}$ Interview with BE (24 February 2014).

${ }^{31}$ Interview with BK, BL, and BM (23 June 2014).

32 Ibid.

33 Interview with BN (11 July 2014).
} 
Q Do you look at the investment chapters of those agreements such as Chapter 11 of NAFTA? Does that come up at all?

A Yeah, where it's relevant. And what our government does is, if we think there is a particular issue, we will get outside expertise to assist in terms of providing that advice to [specific name of provincial Cabinet].

In these interviews with trade officials from other jurisdictions, there were indications that the context may differ from Ontario. At the federal level, apparently there was earlier awareness of NAFTA Chapter 11 and a broader and more intensive process for vetting measures for ISDS risks. 34 In the other large province, the trade official thought there was more Cabinet-level awareness of trade concerns in that province than Ontario; in the smaller province, the official thought there was more sensitivity to trade issues in the province because it was more trade-dependent than Ontario. 35

Incidentally, it appeared that trade concerns can also affect non-governmental organizations. Two interviewees commented that environmental groups must consider trade concerns when proposing initiatives. ${ }^{6}$ Also, a lawyer for an environmental group reported that conservation groups advocating for protection of the Peel watershed in the Yukon had to deal with issues of potential government liability for injurious affection (i.e. indirect expropriation) and propose ways to limit liability, though the lawyer did not point specifically to NAFTA. 37

Based on these and other responses from interviewees, it was clear that trade concerns including ISDS are considered in the decision-making processes of environment-related ministries in Ontario and elsewhere in Canada.

\section{Finding \#2: Government lawyers play a key role in assessing trade and ISDS risks.}

Various interviewees conveyed that trade and ISDS litigation risks are assessed mainly by lawyers in the ministry or in other parts of the provincial government. For example, a long-serving policy specialist in an environment-related ministry said that, for NAFTA, lawyers would advise policy officials on whether there would be a real financial risk for government, including for proposals with risks as low as in the thousands of dollars. ${ }^{8}$

On the general issue of litigation risk in government, the policy specialist replied as follows about the role of lawyers in the ministry and in Cabinet Office: 39

\footnotetext{
34 See the discussion of finding \# 3 below.

35 Interview with BK, BL, and BM (23 June 2014).

${ }^{36}$ Interviews with AE and BA (3 and 10 December 2013).

37 Interview with AC (6 April 2011).

${ }^{38}$ Interview with AZ (26 November 2013).

39 Ibid.
} 
Q Can you recall or imagine any situation where the prospect of judicial review, or any other threat of litigation, would serve as a deterrent to going forward with a particular decision?

A Sure. So first of all, I mean, I'm not a lawyer, so lawyers are going to give... lawyers are involved in every decision. Believe me. And different branches of law. So from those that are experts in legislation and policy to those that are involved in defending claims against the threat of litigation and what not.

The policy specialist later replied to a more specific question on NAFTA and ISDS:40

Q So the lawyers judging what's compliant or not with NAFTA have a major role, kind of a gatekeeping role, on any initiatives?

A Yeah. And they would be tracking NAFTA cases, they would be tracking decisions, even if decisions aren't taken... Because you could spend a ton of money defending yourself against a challenge, right? So again you're better off avoiding that situation, because money's better spent on implementing your things, whatever it is.

The policy specialist also explained:41

As a bureaucrat, it's not something where I go: 'How am I going to go through this decision against NAFTA?' I am going to say: 'There are probably NAFTA implications and we need some advice on how close to the edge of that NAFTA line'.

A long-serving official in another environment-related ministry, who was based in a regional office, told us that, if an outside party such as a company raised NAFTA as an issue with the ministry, then the official would go to a lawyer in the regional office and, after that, the issue could go to a more specialized lawyer in the ministry's central office. $4^{2}$

A lawyer in the same ministry said that there is an informal network of provincial government lawyers who know about trade and investment law. The lawyer estimated that (in and around the early 2010s) there were about ten such lawyers across Ontario ministries, up from two or three in the early 2000s. The lawyers' focus for trade issues was the WTO and NAFTA and they would follow NAFTA ISDS cases that were relevant

40 Ibid.

${ }^{41}$ Ibid.

42 Interview with BH (24 March 2014). 
to their field (e.g. environment) but not other ISDS cases; for the latter, they would rely on federal trade lawyers. 43

For litigation risk in general, a lawyer in another environment-related ministry said that the ministry's lawyers "look at policy submissions and advise whether they're workable from a legal perspective". They "work right from the ground up"; that is, from initial stages of development of a policy proposal to a ministry's Cabinet submission. The lawyer added that the lawyers' role can go beyond strictly legal advice:44

I'll be frank with you. In my view, our role.... as a government lawyer, sometimes the line between law and policy is blurred a little bit.... A lot of lawyers here will sometimes remark and may make comments that are more in the policy realm. The government lawyers come and say, 'well this doesn't make sense' or 'how would this work', or even operational things, as we try to understand things.

The same lawyer indicated that the ministry ramped up its internal trade expertise in the late 2000s.45

A former senior policy advisor in an environment-related ministry stressed the importance of lawyers and of claims of legal expertise in internal discussions. The policy advisor, who was a lawyer, described a dynamic where someone in the ministry "would wave their hands at these kinds of issues [i.e. trade and ISDS] and say we can't move" but that the hand-waving did not have much impact because the minister at the time was also a lawyer. ${ }^{46}$ In other words, because the minister was a lawyer, he or she was able to evaluate skeptically the trade or ISDS concerns raised by bureaucrats. 47

Yet the policy advisor also expressed a concern that, if the minister's advisor was not also a lawyer (and so able to evaluate claims of litigation risk critically) then the advisor may be swayed before a proposal even reached the minister. According to the policy advisor: 48

It's not the usual course to have a lawyer as policy advisor to the minister. So... it may not even get as far as the Minister saying 'I'm a lawyer and I'm not swayed' because the policy advisor may not let it get that far when they're swayed, right?

Further:

And my observation, having been there and seen the kinds of decisions that come through, is that if you don't have an extremely well-informed policy advisor

43 Interview with AH (25 March 2013).

44 Interview with BG (27 February 2014).

45 Ibid.

${ }^{46}$ Interview with AE (15 April 2011).

47 Ibid.

${ }^{48}$ Ibid. 
substantively on the issue - not just on this type of issue [NAFTA Chapter 11] but on all the substantive issues they're dealing with - you can well have a situation where what they're told by civil service is what they feel they have to go along with, regardless of whether it's true or not.

Other interviewees also indicated that legal advice can be critical in internal decisionmaking. After being asked specifically about ISDS and regulatory changes, a longserving policy official in an environment-related ministry said:49

As a bureaucrat at a line ministry you're going to say, 'I want to do it this way'. The lawyer's going to come back and say, 'well I advise against it because it's going to be non-compliant with NAFTA'. So we're going to go, 'so how do I make it compliant with NAFTA?' And they go, 'well if you change it to this way, that'll be compliant with NAFTA'.

Does that completely change how I do things? Yes, no, maybe? You'll factor that in and, 9 times out of 10, you're going to go: 'thanks that's good advice, we're going to modify it'. So by the time it goes through, there is no conflict controversy. Especially on those things where you're trying to make a decision on a new program or a new regulation.

However, the policy official also said that legal advice may not lead to changes in a proposal:50

We might decide, thanks for your advice lawyers, we're going to put that into the bag and we're going to consider it along with all of the other factors that we have to consider. But not necessarily will it be the one factor that sways us from doing one or the other.

This official then described NAFTA risks as one of many kinds of risk considered in policy-making, others including social, reputational, financial, and sustainability risk.

A former federal government lawyer in an environment-related ministry said that the ministry had increased its trade law expertise to be able to evaluate objections to proposed regulations that were raised by the federal trade ministry. According to the interviewee, when "the trade law people" provided an opinion that there was a problem with a proposal: 51

That would have a huge impact in any efforts to develop new regs [regulations]. That could put the brakes on anything. So it became a real question after that of

\footnotetext{
49 Interview with BP (14 July 2014).

5o Ibid.

${ }^{51}$ Interview with AW (22 November 2013).
} 
um, really drilling down into those opinions and seeing that there actually was a problem, or if this was all very very punched up.

A long-serving policy and project officer in the federal development ministry referred to the role of government lawyers when involved in internal decisions. The official spoke of development aid projects involving relations between the agency and outside actors and not specifically about trade or ISDS risks. Even so, the official's perspective helped to illuminate the lawyer's potentially powerful role: $5^{2}$

Q: And when the lawyers come in, is their advice, does their advice more or less drive the decision making or is it just one factor among many?

A: No it tends to drive the decision making and it can be very annoying because the lawyers are super cautious about protecting her majesty, so it generally is very counterproductive developmentally, because we pretty much end up stopping the initiative and we can also have some issues with souring relations, if it's with the partner country for instance. Um, but they are extremely conservative and extremely risk-averse...

Finally, a former political advisor who had had extensive access to Ontario Cabinet decision-making suggested that ISDS pressures on governments are dealt with primarily by government lawyers. When asked about fiscal risks associated with NAFTA Chapter 11 lawsuits, the interviewee said: "If there's a significant risk and a significant economic impact associated with that risk, that's going to have a huge impact". The interviewee then added:53

My view is that if you ask the average minister if there's legal chill associated with trade law, they'd probably say no because they'd probably never seen a decision get to their desk where they've had to look at that. But if you asked---.

Q: They're screened out?

A: Yeah. If you asked an honest lawyer working for government that regularly assesses legal risk of that sort, if they were being honest, they would say that there is.

Based on these comments, we found that the evaluation of trade and ISDS litigation risk was part of a broader risk assessment that revolved around government lawyers. The lawyers' evaluation of such risks could be very significant in internal decision-making and appeared to reflect a cautious, risk-averse approach.

B. ISDS and the provincial trade ministry

$5^{2}$ Interview with AT (15 November 2013).

53 Interview with AX (22 November 2013). 


\section{Finding \#3: The Ontario trade ministry has pushed to expand a centralized regulatory assessment process for evaluating government decisions for trade and ISDS risks.}

From the interviews, we learned that the Ontario trade ministry works to ensure that proposed decisions are reviewed internally from a trade perspective. The ministry's trade concerns arose from NAFTA, the WTO, and Canada's Agreement on Internal Trade.

The ministry pursues this goal in various ways. First, while many proposed decisions would be reviewed for trade issues in the ministry that develops the proposal, the trade ministry also evaluates some proposed decisions. Second, the trade ministry has pushed to expand the vetting of government decision for trade issues, especially at the Cabinet Office (the high-level bureaucratic office supporting Cabinet and reviewing ministry proposals). Third, the trade ministry works to spread awareness about trade agreements across the government.

As an illustration, a well-placed source in the Ontario trade ministry identified two means by which specific proposals may be evaluated by the ministry. The first, involving queries from another ministry, was described as follows: 54

Usually things come to us in one of two ways. One is people in policy and legal branches across the government think there might be some kind of trade angle to a particular regulation that they're passing, maybe because there's a foreign company that's in the sector that might be affected. Or maybe because they went to one of our training seminars years ago [where we] say: 'You know, you shouldn't do things that kind of isolate individual companies that might be perceived as discriminatory and I just want to flag that a little bit. So if you're passing something or thinking of passing something, just run it by us and we can maybe provide the commentary.'

The second means was an evolving "trade policy screen" for proposals passing through the Cabinet and other Ontario central agencies. 55 The source described this means of review: 56

The other is that technically we lobby very hard to try and get what we call a trade policy screen on Cabinet submissions and other kinds of proposals going through to central agencies.... And every now and then we actually have somebody come by and say, 'well, you know, there might actually be a trade policy implication',

\footnotetext{
54 Interview with AF (15 April 2011). The point was corroborated by another trade ministry source; Interview with $\mathrm{AD}$ (15 April 2011).

55 Besides Cabinet Office, the other central agencies in the Ontario government are the Premier's Office, Management Board Secretariat, and the Ministry of Finance.

${ }^{56}$ Interview with AF (15 April 2011).
} 
and they'll come by, usually to [named person in the trade ministry] and [that named person] will see a Cabinet submission or something like that.

A lawyer at an environment-related ministry said that the ministry refers proposals and questions to the trade ministry for evaluation. The lawyer said, "Even though now we have a couple lawyers who do trade, we still involve MEDT [Ministry of Economic Development and Trade] throughout." Indeed, the lawyer said that these consultations were linked to an informal protocol between the lawyer's ministry and the trade ministry: 57

... We are required through a sort of a protocol, so they're the key legal opinion or something on a trade issue. We still have to get it signed off by MEDT.

Q: Okay, so that would be sort of an inter-ministerial protocol, is that right?

A: Well I don't know that it's a formal written protocol but there's certainly an understanding that on key trade things, we need to consult with MEDT.

Q: So, if you identify, hmm this seems to involve trade, we're going to go there.

A: Well, we'll give a call to one of the lawyers over there, yeah.

For this second means of review, a source at the trade ministry said that the ministry's aim was for officials in the Cabinet Office to do a trade policy screen of any proposal before it goes to Cabinet. The source also said that Cabinet Office liaison officials for other ministries may be aware of trade issues and may refer another ministry's proposal to the trade ministry..$^{8}$

However, the trade ministry did not itself review a large number of proposals coming from other ministries, largely due to its limited size and resources. According to another well-placed source in the trade ministry, the trade ministry's main task was to work on the NAFTA Chapter 11 cases against Canada that involved Ontario. 59

Both sources in the trade ministry made it clear that the trade ministry wanted to increase its role and both sources informed us of the ministry's push to augment and formalize vetting for trade issues across the government. ${ }^{60}$ This push, which both of the sources supported, included the fairly recent establishment of a formal regulatory assessment policy - including for trade issues - at the level of Cabinet and Cabinet

\footnotetext{
57 Interview with BG (27 February 2014).

${ }_{58}^{8}$ Interview with AF (15 April 2011).

59 Interview with AD (15 April 2011).

6o Interviews with AD (15 April 2011) and AF (15 April 2011).
} 
Office. ${ }^{61}$ One of the sources confirmed that the policy was meant to capture ISDS risks under the term "trade". ${ }^{6}$

In contrast, a non-governmental policy specialist with many years' experience in the environmental field was critical of the expansion in the role of the Ontario trade ministry. The policy specialist spoke in 2011 about the trade ministry taking part both visibly and behind the scenes in consultations run by the Ontario environment ministry. According to the policy specialist: "They are increasingly behaving, this is new... in the last year... they are now behaving like a central agency.... It's now been 20 years since I've been doing this stuff - I'd never seen that in Ontario." ${ }^{3}$

The policy specialist stressed that Ontario's process of formal regulatory assessment was historically much less developed than at the federal level: 64

This is new stuff for them [the trade ministry]. And they don't have the legal capacity because they're not a regulator, so they don't have, to my knowledge, a whole bunch of counsel who live and breathe this stuff and would be able to present those kind of arguments in a compelling way.

Yet, according to the trade ministry sources, the consideration of trade issues appeared to be increasingly formalized in the manner of the federal assessment process. This development followed partly from the trade ministry pushing for more centralized screening. On whether the new Ontario regulatory assessment policy was a step toward more formalized consideration of trade implications, one trade ministry source said: 65

That's our hope. I mean we're responsible for that regulatory policy [in Ontario].... Most important for us was to post draft regulations. Now unfortunately they're only Order in Council Regulations, they're not Director's Orders or Minister's Orders, but baby steps.

The source added that the trade ministry "is in charge of policing" the new regulatory assessment policy and that it is part of a learning process in government. The trade ministry's aim was not that its dozen or so policy officials would review all proposed regulations but that the Cabinet office "will start insisting on this". Thus: 66

${ }^{61}$ Government of Ontario, "Ontario Regulatory Policy" (July 2014), available at:

https://www.ontariocanada.com/registry/downloads/Ontario\%20Regulatory\%20Policy.pdf (last visited 2 November 2015). We were told that the internal policy dated from 2010. See also J.V. DeMarco and T. Vigod, "Smarter Regulation: The Case for Enforcement and Transparency" (2007), 17:2 Practice 85; M. Winfield, "Environmental Governance in Canada: From Regulatory Renaissance to Smart Regulation" (2006) 17:1 JEL\&P 69.

62 Interview with AF (15 April 2011).

63 Interview with AG (14 April 2011).

64 Ibid.

65 Interview with $\mathrm{AD}$ (15 April 2011).

${ }^{66}$ Ibid. 
through the informal consultations that people make... before they come to Cabinet with a proposal, the Cabinet Office will be saying, 'have you considered this, this and this which is now in our regulatory policy and where is proof of the consultations that have taken place?' So it's really the minders in the centre that we hope will impose the discipline.

Trade ministry officials also sought to expand the role of trade considerations by conducting training sessions for other government officials. According to a lawyer in an environment-related ministry: "Our trade ministry has done a lot of sessions on what the trade rules are, how to be consistent with them.... They do it for policy makers and they do it for lawyers as well." 67

It was intriguing that the advice from trade ministry specialists (who were not themselves lawyers) could be delivered to another ministry through legal advice given by an intermediary government lawyer. That is, another ministry's lawyer may use advice from trade ministry specialists in the lawyer's opinion to the other ministry. One source at the trade ministry told us: 68

They always think that we're lawyers because - no offence - because only lawyers are smart. And then when they find out you're not a lawyer [laughter]. But mostly our relationship is: you're in the legal services branch [of a ministry], your client wants advice, they want it now. Here's somebody [in the trade ministry] who's willing to give them advice and then they just take it and they put it in their opinion as their own. And that's the way you solve the problem that we're not lawyers. That's the way it has worked.

Even so, besides the trade ministry's limited capacity, there were other limitations on the trade ministry's role in vetting proposals. A lawyer in an environment-related ministry said that the reconciliation of trade and environmental issues was done more at the lawyer's ministry than at the trade ministry. The latter became involved "because someone at the environment ministry thought it was a good idea to double check with the trade ministry". 69

Thus, we found that the Ontario trade ministry plays an important but not allencompassing role in vetting proposals for trade and ISDS risks. Trade agreements and ISDS boost the trade ministry's internal position to some degree and the trade ministry pushes for a greater role for itself and for trade concerns in internal decision-making.

\footnotetext{
67 Interview with AH (25 March 2013).

68 Interview with AD (15 April 2011).

69 Interview with AH (25 March 2013).
} 


\section{Finding \# 4: Some insiders saw the trade ministry and the regulatory assessment process as creating undesirable obstacles for environmental decision-making.}

Several interviewees expressed this view when the topic of Ontario's trade ministry arose in the interview. As context for these perspectives, all of the interviewees would have supported environmental initiatives to some degree, whether inside or outside government. The perspectives contrasted with those of trade ministry sources, who supported a greater role for trade concerns in government decision-making.

According to a former policy advisor in an environment-related ministry, "there are lots of opportunities for things to stumble" in policy development, even without the formal regulatory assessment process. ${ }^{0}$ The interviewee was suspicious that internal objections to proposals, including ISDS objections, had come from bureaucrats in the trade or environment-related ministry and not from industry, but were presented by the bureaucrats as objections from outside stakeholders: ${ }^{71}$

I really noticed on some files, when I had a lot of familiarity with the stakeholders [in industry], I knew darned well that stakeholders were not raising those issues and that MEDT [the trade ministry] was raising issues that they thought their stakeholders would or should raise.

Another long-serving former official in an environment-related ministry indicated that the trade ministry was effectively an internal lobby for business. Commenting on local disputes about water takings from stressed groundwater sources, the former official said: 72

The [trade ministry] oversees the interests of - they're greasing the wheels within government to make sure that these kinds of activities [here, water takings by large bottled water companies] are allowed to continue unimpeded, without the intervention of environmentalists or people inside ministries who have progressive agendas.

A scientist in an environment-related ministry, who had had extensive exposure to policy decision-making and was interested to ensure science-based decision-making for environmental protection, indicated that the provincial trade ministry affected internal decision-making and was very pro-business. On the other hand, the scientist said the relevant environment-related ministry did not seem to have a non-business clientele to counter pro-business tendencies in decision-making.73

\footnotetext{
70 Interview with AE (15 April 2011).

${ }^{71}$ Ibid.

72 Interview with AI (1 October 2013).

73 Interview with BT (24 June 2011).
} 
Finally, an environmental lawyer who had not worked in government but had extensive experience in relevant law and policy in Ontario saw regulatory assessment processes as skewed toward industry. According to the lawyer: "There's no shortage of opportunity for those commercial or industrial sectors to make their views known before, during, and after the regulatory decision is made". 74

These perspectives about the trade ministry highlighted that decisions about government processes themselves, even before one gets to the merits of a specific substantive decisions, reflect debates about how trade or foreign investor protection should be weighed against other priorities. The underlying tension is not necessarily resolved by trade agreements or ISDS rulings, leaving room for discretion and debate among decision-makers confronted with a trade concern alongside an environmental priority.

C. ISDS and institutional learning

\section{Finding \#5: A ministry's concern for trade and ISDS became more acute after the ministry was drawn into a NAFTA case, although institutional learning about ISDS appeared variable and intermittent.}

We heard that trade issues were more prominent in a ministry's decision-making after the ministry's past role was the subject of a NAFTA case against Canada. A lawyer with an environment-related ministry reported that, while NAFTA issues were considered as hypotheticals in the early 2000s, the assessments became more real after the Gallo claim against Canada, which involved an Ontario government decision. 75

A lawyer with another environment-related ministry indicated that the ministry had developed its own internal expertise in trade, in the form of two ministry lawyers who now vet internal proposals, after the ministry became involved in one or more NAFTA claims. According to the lawyer: 76

Until we had these trade issues [i.e., involvement in specific cases] in this portfolio, it's not that frequent, but recently it's been all consuming for two or three lawyers within our branch... We've had to develop the trade expertise here now, given that [the ministry's portfolio] is very technical.... And because of that we've had to develop an expertise in trade.

The lawyer also noted a greater attention to trade issues than other international issues: "So we are more attuned to trade issues. But, in terms of other international issues and international compliance, not so much." 77 Further, the lawyer said that the ministry's

74 Interview with AZ (26 November 2013).

75 Interview with AH (25 March 2013).

${ }^{76}$ Interview with BG (27 February 2014).

77 Ibid. 
liaison with the provincial trade ministry had increased in the same period: "Certainly within this branch, it has increased a lot, I think, in the last three years.... There's been more profile given to the trade issues." 78

This finding was corroborated by a trade official from a smaller province who said that in the last few years and in light of recent NAFTA cases - "we have built in that trade perspective much more deliberately". Trade staff in the other large province reported that the consideration of trade concerns had expanded since the early 2000s.79

This finding was also corroborated by sources at the federal level. Various interviewees told us that the first NAFTA claim against Canada, the Ethyl case, in the late 1990s drew much more attention to ISDS. One interviewee was a former federal Cabinet minister who recalled the impact of the early NAFTA cases: 80

Q: Do you think consideration of these things [trade concerns] became more frequent and intense at a certain point of time or has it sort of always been that way in your experience?

A: I think it became more intense after the NAFTA. I think that NAFTA was the... I guess the watershed if you could put it that way, for more legalistic arguments for companies to argue loss, the damage to future lost profits.

On the Ethyl case, in which the U.S. manufacturer of a gasoline additive called MMT used NAFTA to challenge a federal ban on the additive, the former minister added: 81

I remember talking about that [the MMT ban] in caucus. It sounded like a hell of a great idea to me. It's a health and safety issue to a certain extent. It's an environmental issue to a certain extent within our own country. It sounds like the right thing to do. On that one, I don't even know if the [NAFTA] implications at the time were considered. But they sure as hell were considered afterwards.

Speaking of Ethyl, a non-governmental policy specialist who worked extensively with federal environmental officials at the time said: "Once the MMT thing happened, the universe changed and the trade lawyers inside the federal government, they had been handed this hammer and they were not afraid to use it." 82

\footnotetext{
78 Ibid.

79 Interview with BN (11 July 2014).

80 Interview with BE (24 February 2014).

${ }^{81}$ Ibid.

82 Ibid.
} 
Similarly, a former federal government lawyer in an environment-related ministry who by the time of Ethyl was no longer in government but kept relevant contacts on the inside - said the case "was a shockwave". The interviewee went on: 83

I get a call from a friend of mine at [a federal environment-related ministry].... I pick up the phone, 'Hi, how are you doing?'; 'Never mind the social... What is Chapter 11 of NAFTA and why are we being sued under it? I swear to God, that was the conversation.

Finally, a former high-level policy advisor in the federal government at the time of Ethyl, in the federal trade department, stated as follows: 84

Q: So maybe if I can just turn to that example [the Ethyl case], do you recall how inside government the knowledge of that settlement caused people to maybe shift in their understanding of the role of NAFTA and so on?

A: Well absolutely, in my opinion, that really spooked officials and they became very, in my view, intimidated by Chapter 11 challenges... So in my view it really led to bad advice from officials in the sense that they were just really fearful of developing any productive policy because they viewed that every policy would be subject to some type of trade scrutiny and that Canada would lose.

Q: So when you say officials, do you mean the civil servants advising the political decision-makers or are you speaking more broadly about officials?

A: When I say officials, I mean the bureaucracy, primarily the folks on the trade side of the Department of Foreign Affairs.

Q: So they were spooked by Chapter 11.

A: Absolutely.

Q: And they were spooked because they feared losing?

A: Correct.

However, it also appeared, at least in the Ontario government, that a government's accounting for ISDS risks could be variable and intermittent. A source at the Ontario trade ministry commented on the lack of institutional memory: 85

One of the things about government is that people will make the same mistakes again and again and again because there's so much rotation of senior

\footnotetext{
83 Interview with AW (22 November 2013).

84 Interview with AM (8 October 2013).

85 Interview with AF (15 April 2011).
} 
management.... A lot of lessons don't stay because people don't stay and there's not a lot of mobilized institutional memory.

A policy specialist with an environment-related ministry noted the role played by lawyers - in the ministry, in Cabinet, or at another ministry such as trade - who were involved in a past case and who: "can kind of go, stop, I've seen this movie before. This is where we're heading. This is what it's going to mean. And they'll always just say, are you prepared to make that decision?" 86

Some interviewees also pointed to reasons for Ontario officials to downplay trade concerns. A reason mentioned by various interviewees was the view that the WTO and NAFTA are a federal and not a provincial responsibility. A trade ministry source put it this way: ${ }^{8}$

There's also [the view that] well the federal government entered into these agreements. It's not really for us.... If we get into trouble, we don't have to deal with it. It's the lawyers that have to deal with it. They just go away quietly and deal with it. It's even further than that, it's the federal government that's going to have to deal with it.

As a way to raise awareness about trade and ISDS, the source expressed some desire for Canada to lose cases that involved Ontario government decisions: 88

I would agree that there needs to be something that's seen as more significant in order for people to take it seriously, yeah. And I think because most of the challenges we faced in a trade situation have been relatively small, they haven't been really damaging, people haven't felt that they've had to pay attention to it.

In particular, the source said that it would be positive if Canada lost the then-ongoing Gallo case and if the award against Canada was for a lot of money: 89

If we're going to lose [the Gallo case], I hope we lose big... \$15 million - that's kind of a rounding error, you know?

Q So a big loss would be good because it would deter those kinds of bad policy decisions?”

A At least it would draw the attention of the Ministry of the Attorney General and others around the system to advise differently if a similar kind of measure was

\footnotetext{
86 Interview with BP (14 July 2014).

87 Interview with AD (15 April 2011).

88 Ibid.

89 Ibid.
} 
coming up. There's nothing to guarantee that that advice would be taken, but at least the advice would be offered.

In contrast, a lawyer with an environment-related ministry reacted positively to Canada's successful defence, by that point, in Gallo and hoped that, with a few more such cases, ISDS claims would dissipate: "It's been decided and decided in our favour, which is awesome"; "...luckily we won with Gallo so all we need is a couple other wins and these things will go away". ${ }^{\circ}$

Thus, while the lawyer preferred Canada to win NAFTA cases in order to deter ISDS claims, the trade official preferred Canada to lose in order to augment the consideration of ISDS risks. These differing views hinted at tensions and conflicting values in internal decision-making, though these tensions and conflicts are mostly beyond the scope of this article.

D. ISDS and specific cases

\section{Finding \#6: Officials typically declined to discuss specific cases or decisions.}

Over the course of the interviews, it emerged that it was not realistic to access in-depth information about particular decisions affected by trade vetting. Trade and ISDS concerns clearly were sometimes considered but it was unclear how the concerns impacted specific decisions.

For example, when asked about the specifics of NAFTA and ISDS and whether they impacted decisions, a policy advisor in an environment-related ministry replied: "you know, it definitely has an impact on our thinking about how we go forward" but did not respond directly when asked about potential chill on regulation, saying:91

"That's a really good conversation to have with the environmental regulators. If you can get yourself a conversation with those folks, I think that you'd get some very interesting perspectives and, you know, I mean, that's as much as I'll say on that."

In declining to discuss specifics, the policy advisor also said: "this is a very risk averse organization... they don't even like it when we talk about stuff."92

A lawyer at an environment-related ministry highlighted a particular need for confidentiality when discussing decisions that had not led to an ISDS claim. The reason was to safeguard against litigation risk: "You don't want to talk about things that maybe

\footnotetext{
90 Interview with AH (25 March 2013).

${ }^{91}$ Interview with BJ (28 March 2014).

92 Ibid.
} 
didn't turn into something. Something is done and it's in the newspaper, we can talk about it freely. It's done... that's in the public domain."93

Similarly, a trade ministry source declined to speak about specific examples involving the environment ministry. When asked about the Gallo case and whether underlying decisions had been vetted for trade concerns, the source said: "I know the exact answer to that but I don't know if I'm allowed to say under the confidentiality agreement." 94 As well, a former political advisor who had extensive access to Cabinet decision-making declined to speak about what happened on any specific files. 95

Staff in the trade ministry of another large province also declined to speak about specifics of the proposals reviewed for trade implications. ${ }^{6}$ The trade specialist in a smaller province did the same, indicating on the issue of disclosing information about the ministry's internal vetting that: "Our problem is obviously there may be risks that we have identified that we certainly have identified as risks that could get triggered...."97

When interviewees expressed a preference not to speak about specifics, we did not press them, turning instead to a discussion of information that would support general findings.

At times, it proved difficult to speak to government lawyers. A legal director in one Ontario ministry denied access to several lawyers working in the ministry who were approached for an interview, even on the understanding that matters of solicitor-client privilege would not be discussed. The lack of access to a wide range of lawyers, who evidently played a prominent role in vetting proposals, limited our ability to learn how specific decisions were affected by trade and ISDS concerns. As we heard from a nongovernmental policy specialist who was familiar with government decision-making: 98

The problem is you have a paper trail per se is limited with this stuff. It's all conversations at meetings or stuff that might have come in a memo, but you can never get it because it would be considered legal advice to government anyway.

In turn, the limited access to lawyers and to specific ISDS risk assessments precluded a comprehensive or representative review of the frequency of ISDS risk assessments, the weight given to the risks, the content of the assessments, or the merits of resulting specific changes to proposed decisions.

93 Interview with AH (25 March 2013).

94 Interview with AF (15 April 2011).

95 Interview with AX (22 November 2013).

${ }^{6}$ Interview with BK, BL, and BM (23 June 2014).

97 Interview with BN (11 July 2014).

${ }^{98}$ Interview with AG (14 April 2011). 


\section{Finding \# 7: Officials referred occasionally to specific situations where trade or ISDS concerns were considered and, in some cases, where they led to changes to a specific proposal.}

About half of the interviews from Canada recalled one or a few situations in which ISDS or other trade concerns were raised in internal decision-making. However, interviewees usually declined to discuss or were unable to recall details. Also, the ISDS or trade concerns seemed to be one of multiple factors affecting how officials approached a decision. Thus, examples of vetting of specific decisions emerged but, without extensive investigative research, it was unclear how a decision was changed. We have identified below a few examples of such reports.

- A long-serving former environmental official in Ontario recalled seeing references to trade issues in legal opinions from the trade ministry on the environment ministry's proposals for a very small tax on water takings (instead of a more restrictive policy to conserve water) or "water charges" in Ontario. 99 The official said that trade concerns arose in a discussion of policies on low water response and water bottling. Similarly, a former policy advisor at an environment-related ministry said that trade concerns, especially NAFTA Chapter 11, were considered for proposals on water takings, after the concerns were raised by the provincial trade ministry in opposition to proposals for water charges and on behalf of "the water bottlers of this world". The concerns were evaluated by the environment-related ministry and eventually considered low risk because the amounts of water charges had been kept very low. ${ }^{100}$

- Two interviewees in government and three in environmental organizations said that the threat of a NAFTA ISDS lawsuit, as part of an industry lobbying campaign against a proposed ban on cosmetic use of pesticides, did not deter Ontario from adopting a strong ban because, by that point, the government was highly committed to the legislation, was supported by mainstream health and environmental groups, and had broad public support.101

- A former high-level policy advisor in the federal trade department said that trade considerations were "the driver to the whole process" for the federal government's decision not to introduce a national prohibition on the bulk removal of water from Canadian waterways (and instead pursue a weaker option). ${ }^{102}$ The source said: "they were concerned that, if bulk water approvals were permitted to American firms, that would make them susceptible to fair treatment claims by other corporations that

\footnotetext{
99 Interview with AI (1 October 2013).

100 Interview with AE (15 April 2011).

${ }^{101}$ Interviews with AD (15 April 2011), AE (15 April 2011), AL (4 October 2013), AQ (18 October 2013), and BA (3 and 10 December 2013). See Ontario Pesticides Act, RRO 2009, REg 63/09.

102 Interview with AM (8 October 2013).
} 
wanted to enter the Canadian market...." and that "the federal government never came out and took a strong stand on this issue because they were afraid of the ramifications from an international trade perspective and the elevation of risk for Canada of stating something strongly and categorically." 103 Three sources in the Ontario government also mentioned more obliquely that trade concerns were considered on the issue of bulk water exports from Canada. ${ }^{104}$

We suspect that there may be some cases where an outside researcher, with limited resources and no formal investigative powers, will be able to identify situations in which ISDS risks were a predominant factor in the evolution of a proposed decision. However, in most cases, if ISDS risks are a factor, we expect they will have played an indeterminate role as part of a mix of factors affecting that evolution.

Along these lines, some interviewees conveyed that trade and ISDS concerns operate "in the background" and that they have a subtle effect on decision-making. The point was made among others by a former federal minister: ${ }^{105}$

Q: So one more question. And you might not be able to answer it, but can you remember any specific files where the trade agreement was a really significant factor, saying okay we're not going to go ahead with this?

A: Don't think so. There's none that comes to mind. You'd think I'd remember something like that. No, I don't think so. It was always, the trade agreements and their impact on decision making was often more subtle. Yes it would be in some of the memorandums to Cabinet, but it was always just kind of a subtle thing that was there. You know, we should be aware of this.

Q: So it's kind of built in.

A: Yeah, it's kind of built in, it's kind of the reality of the world. It's one of the factors you'd have to consider. And I do think it affects decision making more than even those that are making the decisions realize. I think it affects how you think..... You're weighing it against, before you even make a decision, against the implications of a trade agreement that's going to affect how you make that decision.

Conclusion

Our findings revolve around the question of whether governments, especially in relation to environmental protection, have changed their decision-making due to ISDS. They elaborate on how decisions are vetted internally and to the role played by government

\footnotetext{
103 Ibid.

104 Interviews with AD (15 April 2011), AF (15 April 2011), and AH (25 March 2013).

105 Interview with BE (24 February 2014).
} 
lawyers and trade officials in the vetting process. The findings also highlight the challenges of investigating specific decisions linked to ISDS.

Besides the limitations noted earlier in this paper, we emphasize that our findings are not exhaustive. We have prioritized reporting of the findings presented here because they were widely-supported by our interviews and reveal a phenomenon of internal vetting not previously examined in the literature. In other publications, we plan to elaborate findings on these further issues:

- Dynamics of internal vetting: incentives that ISDS creates in government, forms of ISDS risk assessment, value choices in ISDS risk assessment, and how ISDS appears to shift decision-making in favour of certain actors.

- Institutional context for internal vetting: locations in government where ISDS risks appear to be assessed, impact on the trade ministry's position within government, and ISDS issues in a federalist system of government.

- Impacts of internal vetting: prospect that ISDS risks will have less impact for governments that are not active in the environmental field, circumstances that may help a proposed decision to proceed despite ISDS risks, prospect that governments may conceal information on ISDS impacts, and utility and limitations of ISDS for foreign investors.

These further issues and findings are premised on the core findings reported here that ISDS has led to internal vetting of proposed decisions in government and that some officials have a greater role in the vetting process than others do. We suggest that these findings are relevant to an evaluation of the impact of ISDS for governments and the public. 